\title{
The Effect of Implementation of Guided Inquiry-Based Model Towards Students' Science Process Skill and Achievements on The Topic of Salt Hydrolysis in Natural Science Eleventh Grade SMA Negeri 1 Binjai
}

\author{
Anna Juniar $^{1}$, Albinus Silalahi ${ }^{2}$, Retno Dwi Suyanti ${ }^{3}$ and Dewi Sartika ${ }^{4}$ \\ \{anna.juniar@ymail.com\} \\ Department of Chemistry Education, Universitas Negeri Medan, Indonesia ${ }^{1,2,3,4}$
}

\begin{abstract}
This research purposed to find outthe increasement of students' achievement which taught by using guided inquiry-based model higher than conventional model, the increasement of students' science process skill which taught by using guided inquirybased model higher than conventional model, and the significant correlation between students' achievement with science process skill by implementing guided inquiry-based model. The population of this research is all students of natural science elevent grade SMA Negeri 1 Binjai in the year academic of 2017/2018. Analysis technique was done by using gain test, normality test, homogeneity test, right-sided t-test, and correlation test. As result: 1) the increasement of students' achievement which taught by using inquiry-based model is higher than the conventional model with t-table (1.666) $>\mathrm{t}$ statistics (3.700) for cognitive domain, t-statistics (4.208) for affective domain, and tstatistics (4.798) for psychomotor domain, 2) the increasement of students' science process skill which taught by using guided inquiry-based model is higher than conventional model with t-statistics $(4.376)>\mathrm{t}$-table $(1.6663), 3)$ there is significant correlation between students' achievement with science process skill by implementing guided inquiry-based model with very high criterion respectively $0.900,0.860$, and 0.819 for cognitive, affective and psychomotor domain.
\end{abstract}

Keywords: Guided inquiry, science process skill, students' achievement, salt hydrolysis.

\section{Introduction}

The process of natural science's learning, especially chemistry, one of the elements that need to be handled properly to improve the quality of students. The subject of chemistry becomes very important in its position in societysince chemistry is around us in everyday life

Essentially, chemistry is the way of finding out and understanding about nature systematically. Chemistry is not taught simply by providing an understanding of definitions, facts, concepts, principles, but also an invention through an experiment process with real action. Based on the characteristics of chemistry, the learning of chemistry today is not only emphasized on the product but also in the process. Since mastery of a good process will produce good products (Utami, et al., 2013).

The role of the teacher in learning which emphasizes the process is only as a mentor and director, meanwhile the activator of process is the student himself. Mastery of the process requires scientific skills which included in science process skill. Science Process Skills is the 
development of physical and mental skill which originate from a person's basic abilities (Semiawan, 1992). Science process skills are techniques or strategies used by scientists to obtain the information.

The abilities which are developed in science process skills consisted of observation, classification, interpretation, prediction, asking the questions, hypothesis, experiments planner, using tools and materials, concept's application, also communication(Rustaman, 2005). The result of Gabel's research in 2006 states that majority of students can work on questions and are trained in mathematical calculations, but lack understanding in the chemical concepts which based the problem [4]. Therefore, the teaching and learning process of salt hydrolysis should emphasize the concept of acquisition process, such that students may not only calculate the $\mathrm{pH}$ but also understand the concepts underlying the problem.

The result of interview with Mrs. Dra. Lorista Pane, as the teacher of chemistry subject at SMA Negeri 1 Binjai shown that the chemistry learning process still tends to be teacher centered. Teacher taught more often using the discourse method, where students were given direct concepts by the teacher then students worked on questions based on the concept. In addition, students were not understood the concept of salt hydrolysis material. This happened because the teacher only cramming the material without involving students to find their own concepts, such that the students were only encouraged to memorize without to know the underlying concepts. The brains of children who are forced to hoard and remember various information without being required to understand it formed graduates who are only theoretically smart but poor in application (Wardani \&Priyani, 2009).

The using of chemical laboratories at SMA Negeri 1 Binjai was not optimal, since the practicum activities are still rarely carried out. When the practicum was carried out, students only followed the instructions or workflow demonstrated by the teacher. Practical instructions ware used in direct instruction and did not activate students such that students' science process skills are underdeveloped (Arifin, et al., 2015).

The tendency of that learning causes students' science process skill is not developed. This is caused by the learning process students which not giving the opportunity to practice their science process skill. Consequently, students' knowledge is not meaning-ful, even students only memorize knowledge such that it does not last long. Meaningful learning will not be realized only by listening to lectures or reading other people's experiences. Experiencing by theirself is the key of meaningfulness (Trianto, 2010). Therefore, it needs an effort to improve science process skill. One of them is applying the Guided Inquiry learning model.

Guided Inquiry is a teaching model which allows students to move step by step from identifying problems, defining hypotheses, formulating problems, collecting data, verifying results, and drawing conclusions under the direction of the teacher (Matthew \& Kenneth, 2013). Guided Inquiry learning is applied to students such that they are independent to develop the concepts which they learned not only limited to the material which recorded and memorized. In addition, the Guided Inquiry model can improve understanding of concepts and motivation to learn because students are actively involved in conducting investigations. This investigation has learning stages that usable to train science process skill (Wulanningsih, et al., 2012).

\section{Research Methodology}

This research has been done at SMA Negeri 1 Binjai on Salt Hydrolysis material. This research was carried out from January to May in the 2017/2018 academic year. In this time interval, survey activities, research proposal preparation, research process, and research report preparation are included. 
The population in this study were all students of SMA Negeri 1 Binjai class XI MIA of even semester 2017/2018 academic year with 2013 curriculum. SMA Negeri 1 Binjai consisted of 7 classes, namely class XI MIA 1 to XI MIA 7 with an average class of 40 students. The sample in the study was taken by using purposive sampling technique, where the researcher determines the sample to be examined directly. This is done because the teacher is the same, then we wish that the teaching time is not too far apart, the teaching materials are same, and the students' initial abilities are also the same, such that it will facilitate the research process.

The class samples took 2 classes, namely XI MIA-1 class as the experimental class which given instruction through the Guided Inquiry learning model and the XI MIA-3 class as the control class which was taught with Conventional learning models. The students' samples for each class were 38 students.

The independent variable of the study is the using of Guided Inquiry model. The dependent variable is an increase in the achievement of cognitive domains and students' science process skill, achievement of the affective and psychomotor domains of students about Salt Hydrolysis. Research control variables are the same teachers who teach, the same student handbook, the same time allocation, the same taught material, and the same pretest-posttest questions.

The design of this study is the Quasi -Experimental with type of Non-equivalent Group pretest-posttest design by using two classes, namely experimental class, and control class. The data collection method of this study used a test of science process skill in the form of 10 essay questions and cognitive domain achievement (20 multiple choice questions), affective and psychomotor observation sheets, also questionnaires of student responses to the model.

The results of this study were analyzed in stages, namely: the increasement test (gain) of students' achievement and science process skill, normality test, homogeneity test, correlation test, and hypothesis testing. The hypothesis test which was used in this study is the right-sided t-test.

\section{Results And Discussion}

Analysis of pretest data on achievement of cognitive domain and science process skill of students was obtained by average value of students' pretest in the sample class of SMA Negeri 1 Binjai which was not much different between the experimental class and the control class. This shows that sample departs at the same initial state. Analysis of the final posttest data on cognitive achievement and science process skill in each class showed a significant difference. Normalized mean and gain of students in experimental class are higher than average and normalized gain in achievement of cognitive domain also science process skill of control class. Data on average pretest and posttest including the gain of cognitive achievement and science process skill is given in Table 1 below. 
Table 1: Summary of average value in both class.

\begin{tabular}{ccccc}
\hline \multirow{2}{*}{ Class } & Variable & \multicolumn{2}{c}{ Average } & Gain \\
\cline { 3 - 4 } & Pretest & Posttest & \\
\hline \multirow{2}{*}{$\begin{array}{c}\text { Experimen } \\
t\end{array}$} & $\begin{array}{c}\text { Cognitive } \\
\text { Achievement }\end{array}$ & 33.03 & 85.39 & 0.78 \\
\cline { 2 - 4 } & $\begin{array}{c}\text { Science } \\
\text { Process Skill }\end{array}$ & 35.15 & 84.91 & 0.77 \\
\hline \multirow{4}{*}{$\begin{array}{c}\text { Cognitive } \\
\text { Achievement }\end{array}$} & 30.00 & 80.26 & 0.72 \\
\cline { 2 - 4 } & $\begin{array}{c}\text { Science } \\
\text { Process Skill }\end{array}$ & 34.70 & 79.29 & 0.68 \\
\hline
\end{tabular}

Based on Table 1, the increasement of students' achievement and science process skill in the experimental class (Guided Inquiry) is higher than the control class (Conventional). Interesting thing from table above is the percentage of gain of cognitive achievement in both class is not quite different significantly meanwhile in science process skill has significant difference. This means Guided Inquiry model impacted so much to the students' process skill. Now, take a look to the graph for the achievement improvement and science process skill for both of experimental class and control class which is given in Fig. 1. Although both classes has same level of low initial cognitive achievement and science process skill, Guided Inquiry in experimental class gives better result to the students. Furthermore, from the posttest data of students' achievement, an analysis of the learning indicators accomplishment was done.

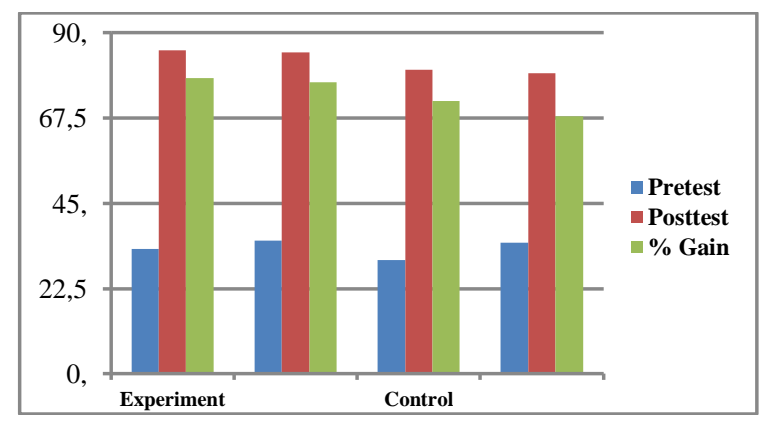

Figure 1: Increasement of students' achievement in cognitive domain and science process skill.

The results of the analysis of the indicators accomplishment of salt hydrolysis material is given in Fig. 2 as below. 


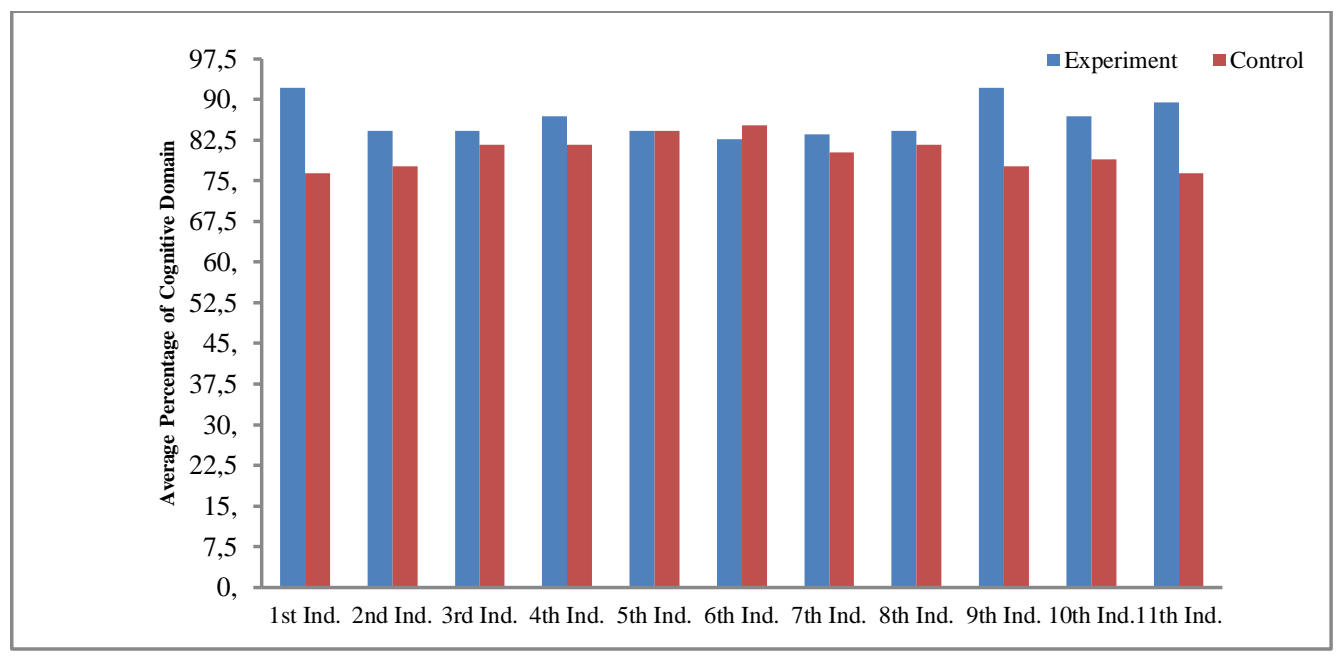

Figure 2: Increasement of students' achievement in cognitive domain and science process skill.

In this study, observation on six aspects of science process skills were done consisted of observing, hypothesizing, grouping, designing experiments, implementing concepts, and interpreting. The gain of each aspect was calculated to find out which aspects of the science process skill experienced the highest increase. The increasement percentage in each aspect of the science process skill from both classes is presented in Table 2 .

\begin{tabular}{ccc} 
Indicator & Experiment & Control \\
\hline Observing & 79.29 & 76 \\
Hypothesizing & 78.31 & 61.12 \\
Classifying & 75 & 74 \\
Planning Exp. & 77.55 & 60.55 \\
Applying concept & 75 & 73.14 \\
Interpreting & 76 & 74.24 \\
\hline
\end{tabular}

Based on Table 2, we may describe the difference of gain percentage of science process skill from the average value in experimental and control class which given by the graph in Fig. 3. 


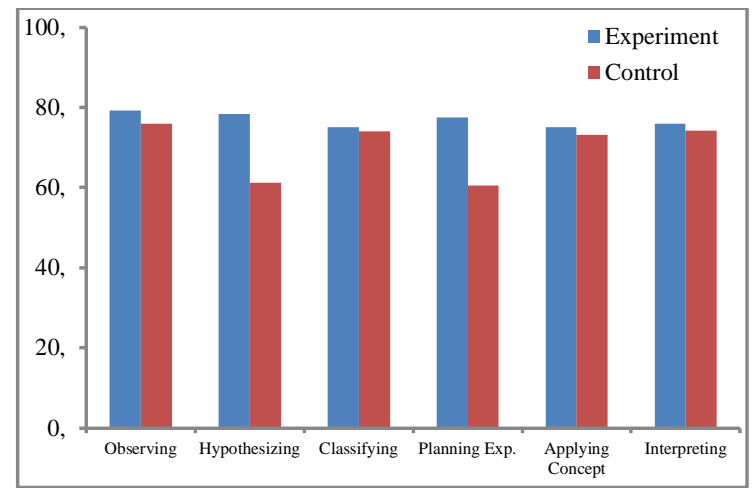

Figure 3: Gain increasement of science process skill.

The data analysis result of cognitive achievement's gain obtained t-statistics $=3.700$ meanwhile t-table $=1.666$. Furthermore, the data analysis result of science process skill's gain obtained t-statistics $=4.376$ meanwhile $\mathrm{t}$-table $=1.666$. So that, it may be concluded that $\mathrm{t}$ statistics > t-table which means that the improvement of cognitive achievement and the improvement of students' science process skills which were taught by Guided Inquiry learning model is higher than students who were taught with the conventional model. The high increasement in science process skills was also caused by using of guided inquiry methods at each meeting which were supplemented by the Student Worksheet (LKPD). Student Worksheet (LKPD) as an instrument for teaching and learning activities provides syntax of guided inquiry learning on it (Fajarida, 2016).

In addition of cognitive achievement and science process skills, this study also observed students' affective and psychomotor achievement. Data of affective and psychomotor achievement of students are given in Table 3 below.

Table 3: Summary of increasement percentage in other domains of achievement.

\begin{tabular}{ccc}
\hline Class & Variable & Average \\
\hline \multirow{2}{*}{ Experiment } & Affective & 89.14 \\
& Psychomotor & 85.64 \\
\multirow{2}{*}{ Control } & Affective & 88.57 \\
\cline { 2 - 3 } & Psychomotor & 84.54 \\
\hline
\end{tabular}

Based on the affective observation, it obtained an average for the experimental class with very a good category meanwhile control class with good category. Moreover, the psychomotor observation of st

udents during the learning process obtained average for the experimental class with very good category and control class with a good category. Here is given the figure of the mean difference between affective and psychomotor values in both classes. 


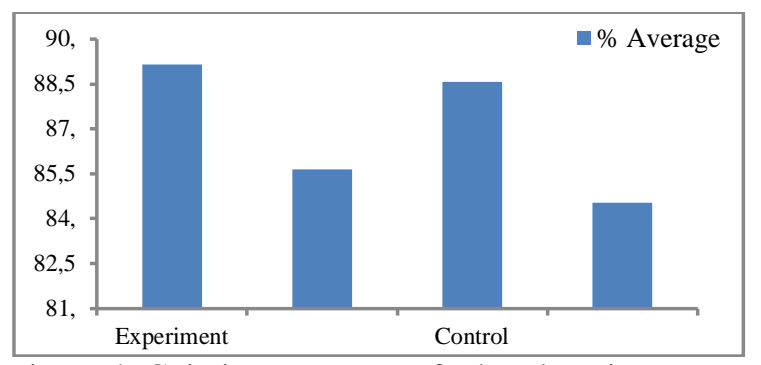

Figure 4: Gain increasement of other domains.

The data analysis result of affective and psychomotor achievements obtained t-statistics $=$ 4.200 (affective) and 4.798 (psychomotor) meanwhile t-table $=1.666$. So, we may conclude that affective and psychomotor achievements of students who were taught by the guided inquiry learning model are higher than students who were taught with conventional learning. Furthermore, a correlation test was conducted between the achievements and science process skill in the class which was taught by the Guided Inquiry learning model. This test was done to find out the hypothesis in this study is accepted or rejected. For cognitive achievement, the variable $\mathrm{X}$ is the increase (gain) of achievement and variable $\mathrm{Y}$ is an increase in science process skill. Testing criteria is: if r-statistics > r-table then the alternative hypothesis is accepted and the null hypothesis is rejected. Data of the correlation test between students' achievement and science process skill is given in Table 4.

Table 4: Summary of correlation between students' achievement and science process skill.

\begin{tabular}{|c|c|c|c|}
\hline Correlation & r-stat. & r-tab. & Explanation \\
\hline $\begin{array}{l}\text { Gain of Cognitive- } \\
\text { Science Process (1) }\end{array}$ & $\begin{array}{l}0.9 \\
000\end{array}$ & & $\begin{array}{c}\mathrm{Ha} \\
\text { accepted }\end{array}$ \\
\hline $\begin{array}{l}\text { Gain of Affective- } \\
\text { Science Process (2) }\end{array}$ & $\begin{array}{l}0.8 \\
601\end{array}$ & $\begin{array}{c}0 . \\
320\end{array}$ & Ha accepted \\
\hline $\begin{array}{l}\text { Gain of Psychomotor- } \\
\text { Science Process (3) }\end{array}$ & 0.8193 & & Ha accepted \\
\hline
\end{tabular}

Table 4 above shows that there is a positive and significant correlation between students' achievement of cognitive, affective, and psychomotor domains with science process skill which were taught by the Guided Inquiry learning model. The contribution of students' achievements toward ups and downs of science process skill is $81 \%$ (cognitive); $73.97 \%$ (affective), and $67.12 \%$ (psychomotor). The graph of correlation test between students' achievements in experiment class is presented in Fig. 5 below. 


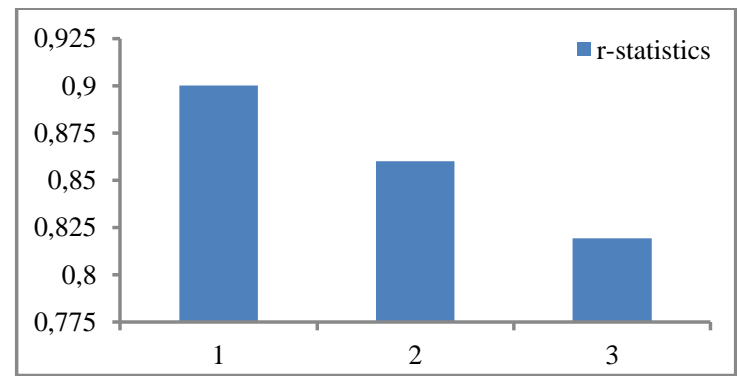

Figure 5: Correlation test between students' achievements and science process skill, respectively (1) cognitive, (2) affective, and (3) psychomotor domains.

At the end of the discussion meeting, students are given questionnaire to determine students 'responses to the guided inquiry learning model. This questionnaire contains 10 items. The following is a graph of students' responses toward guided inquiry learning model in Fig. 6.

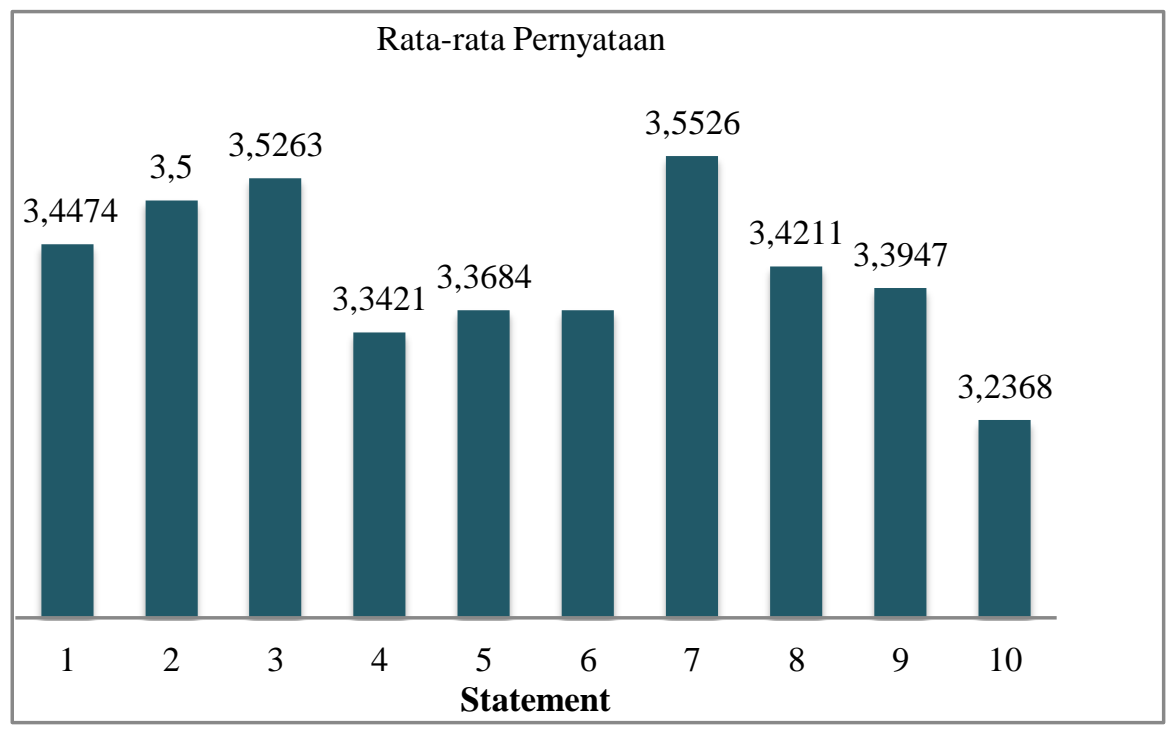

Figure 6: Average of students' responses toward guided inquiry learning model.

Explanation:

1. I am happy and motivated to study chemistry using the Guided Inquiry learning model.

2. The guided inquiry learning implementation makes me easy to understand salt hydrolysis material.

3. Implementation of Guided Inquiry learning can increase my curiosity.

4. Learning chemistry with Guided Inquiry learning model gives me the opportunity to argue and exchange ideas with friends in discussions. 
5. Problems which given by researchers encourage me to gather information from various sources.

6. I feel happy to design my own experiments in practicum activities.

7. With the learning model provided by researcher, I became aware of several chemical concepts related to everyday life.

8. The implementation of learning with Guided Inquiry model can improve my ability to remember a concept of salt hydrolysis for longer.

9. The implementation of learning with the Guided Inquiry model is suitable for salt hydrolysis material.

10. The implementation of learning with the Guided Inquiry model needs to be applied to other topics in chemistry.

Generally, students give positive responses to the study of salt hydrolysis by using guided inquiry learning model. This is proven when the learning process takes place, students feel like learning chemistry with guided inquiry learning modelbecause in this learning students are actively involved starting from formulating problems, submitting hypothesis, designing an experiment, collecting data, analyzing data, and making conclusions. Learning activities became more meaningful and easier for them to understand also remember the subject matter because they can find the concept of the subject matter independently. This is consistent with previous research that Science Process Skill is based on scientific inquiry and teaching science with inquiry makes students learn to think the critical and very effective approach to teaching that helps students to understand concepts well (Yager \& Akcay, 2010).

Guided Inquiry learning is applied such that students are independent to develop the concepts they learn not only limited to the material recorded and memorized. In addition, the Guided Inquiry model able to improve understanding of concepts and motivation to learn because students are actively involved in conducting investigations. This investigation has learning stages which are usable to train science process skill (Wulanningsih, et al., 2012).

Almuntasheri, et al in 2016 linked the effectiveness of Guided Inquiry with its learning environment where students are encouraged to control their own learning with the guidance given by the teacher (Almuntasberi, et al., 2016). In such learning approaches, students become more aware of the contradictions between their pre-knowledge and the new concepts learned through their own scientific explanations, which come from their own data analysis. Even though questions are given by teachers in Guided Inquiry activities, students are leaders of the investigation process and involve themselves in motivational thinking, this then allows them to reach their own conclusions.

\section{Conclusions}

After conducting research, calculating data and testing hypotheses, the researchers obtained the following conclusions:The increasement of students' achievement which was taught by using Guided Inquiry model is higher than the increasement of students' achievement which were taught by using conventional model. In the Salt Hydrolysis material, we obtained t-statistics for cognitive domain $=3.700$, affective domain $=4.208$, and psychomotor domain $=4.798$ which are greater than $\mathrm{t}$-table $=1.666$. The increasement of students' science process skill which was taught by using the Guided Inquiry model is higher 
than the increasement of students' science process skill which were taught using the conventional model. In the Salt Hydrolysis material, we obtained t-statistics $=4.376>\mathrm{t}$-table $=1.666$. There is a significant correlation between students' achievement with science process skill through the application of the Guided Inquiry model. In the Salt Hydrolysis material, we obtained the correlation between science process skill with respectively cognitive domain $=$ 0.9000 , affective domain $=0.8601$ and psychomotor domain $=0.8193$ which greater than $r$ table $=0.3200$. The contribution of students' achievement t0ward ups and downs of students' science process skill is $81 \%$ (cognitive), $73.97 \%$ (affective), and $67.12 \%$ (psychomotor).

\section{References}

[1]Almuntasheri, S., Gillies, R. M., and Wright, T., 2016. The effectiveness of a guided inquiry-based, teachers' professional development programme on saudi students' undertstanding of density, Science Education International.

[2]Arifin, U. F., Hadisaputo, S., and Susilaningsih, E.. 2015. Pengembangan lembar kerja praktikum siswa terintegrasi guided inquiry untuk keterampilan proses sains, Jurnal Inovasi Pendidikan Kimia.

[3]Fajariyah, N., 2016. Penerapan model pembelajaran inkuiri terbimbing untuk meningkatkan kemampuan berpikir kritis dan prestasi belajar pada materi kelarutan dan hasil kali kelarutan siswa kelas xi SMA al islam 1 surakarta tahun ajaran 2014/2015, Jurnal Pendidikan Kimia $(J P K)$.

[4]Gabel, D., 2006. Problem-solving skills of high school chemistry students, Journal of Research in Science Teaching, Vol. 21 (2). [Online]. Available in http://onlinelibrary.wiley.com/doi/10.1002/tea.3660210212/pdf

[5]Matthew, B. M., Kenneth, I.O., 2013. A study on the effects of guided inquiry teaching method on students' achievement in logic,International Researcher.

[6]Rustaman. 2005. Strategi belajar mengajar biologi. Bandung: UPI Press.

[7]Semiawan, C., 1992. Pendekatan keterampilan proses. Jakarta: PT. Gramedia.

[8]Trianto. 2010. Mendesain model pembelajaran inovatif progresif. Jakarta: Kencana Prenada Media Group.

[9]Utami, W. D., Dasna, W., Sulistina, 2013. Pengaruh penerapan model pembelajaran inkuiri terbimbing terhadap hasil belajar dan ketrampilan proses sains siswa pada materi kelarutan dan hasil kali kelarutan, Jurnal Pendidikan Kimia UNM.

[10]Wardani, W., Priyani, N. E., 2009. Peningkatan hasil belajar siswa melalui pendekatan keterampilan proses sains berorientasi problem-based instruction, Jurnal Inovasi Pendidikan Kimia.

[11]Wulanningsih, S., Prayitno, B.,Probosar, R., 2012. Pengaruh model pebelajaran inkuiri terbimbing terhadap keterampilan proses sains ditinjau dari kemampuan akademik siswa sma negeri 5 surakarta, Jurnal Pendidikan Biologi.

[12]Yager, R. E., Akcay, H., 2010. The advantages of an inquiry approach for science instruction in middle grades, School Science and Mathematics I. 